\title{
"The role of some indicators of financial security in Ukraine in the context of transnationalization and national interests"
}

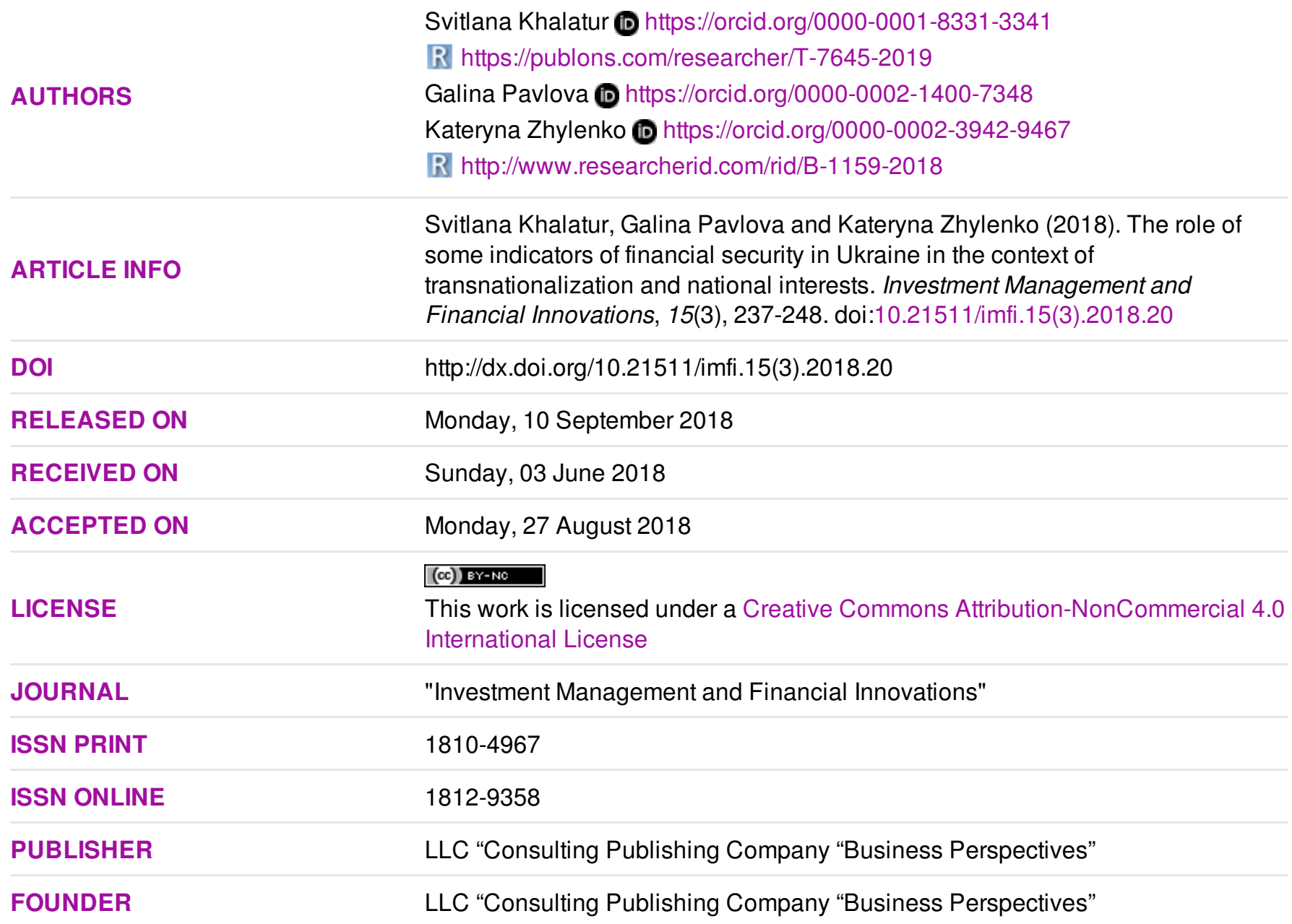

NUMBER OF REFERENCES

29

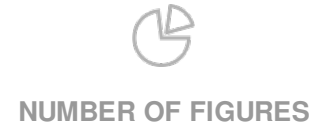

3
NUMBER OF TABLES

5

(C) The author(s) 2022. This publication is an open access article. 


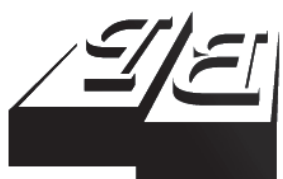

BUSINESS PERSPECTIVES

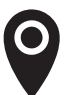

LLC "CPC "Business Perspectives" Hryhorii Skovoroda lane, 10, Sumy, 40022, Ukraine

www.businessperspectives.org

Received on: $3^{\text {rd }}$ of June, 2018 Accepted on: $27^{\text {th }}$ of August, 2018

(C) Svitlana Khalatur, Galina Pavlova, Kateryna Zhylenko, 2018

Svitlana Khalatur, Doctor of Economics, Assistant Professor of Finance and Banking Department, Dnipro State Agrarian and Economic University, Ukraine.

Galina Pavlova, Doctor of Economics, Professor of the Department of Accounting, Audit and Management of Financial and Economic Security, Academician in AENU, Director of the Educational and Scientific Institute of Economics, Dnipro State Agrarian and Economic University, Ukraine.

Kateryna Zhylenko, Ph.D., Assistant Professor, Department of Management and Tourist Business, Oles Honchar Dnipro National University, Ukraine.

\section{(ㄷ)(1) $(9$}

This is an Open Access article, distributed under the terms of the Creative Commons Attribution-NonCommercial 4.0 International license, which permits re-use, distribution, and reproduction, provided the materials aren't used for commercial purposes and the original work is properly cited.

\section{THE ROLE OF SOME INDICATORS OF FINANCIAL SECURITY IN UKRAINE IN THE CONTEXT OF TRANSNATIONALIZATION AND NATIONAL INTERESTS}

\begin{abstract}
The article analyzes some indicators of Ukraine's financial security in the context of transnationalization and national interests. On the basis of the obtained results, the role of financial security in the context of transnationalization and national interests has been determined, directions for strengthening the financial security of the country have been proposed.
\end{abstract}

The main objective of the study is to determine the role of Ukraine's financial security in the context of transnationalization and national interests, based on the study and evaluation of some financial security indicators. The methodology of the research is based on the early prevention of threats to financial security of Ukraine in the context of transnationalization and national interests, based on both macroeconomic and financial data from the entire financial system. The regression models were used, because they work dynamically and change as information changes. Diagrams can be used by financial analysts to understand the investment attractiveness of the country at the current time with the current level of financial security. Standard models are designed to predict the financial stress and threats to financial security. Financial security models must be built with the support of macroeconomic knowledge, assessment of other risks and expert interpretations, used to get the highest value in the research.

The procedure of simulation of financial security indicators of the country has been given. The use of correlation and regression analysis for forecasting the financial security indicators in Ukraine has been substantiated. The links between the indicator variables have been analyzed. The general view of model relations between financial security indicators in Ukraine has been determined, their statistical analysis has been carried out and the necessity of forecasting the financial security indicators of Ukraine has been substantiated.

Keywords

financial security, national economy, growth relationship, indicators

\section{JEL Classification E51, O16}

\section{INTRODUCTION}

Financial security is particularly important for the redistribution of capital in the framework of transnationalization, and thus provides the basis for the continuous restructuring of the economy necessary for maintaining growth. Countries with a highly developed financial system have a larger share of investments, which is allocated to relatively rapidly growing sectors of the national economy. Nowadays, in Ukraine, the absence of developed stock market is a serious drawback and a threat to the country's financial security. Innovative high-tech firms should become the key factors of future structural changes supporting the long-term growth potential of the country. The contribution of financial markets in this area is the essential necessity for preservation of competitiveness of the modern economy. This com- 
petitiveness can be saved under conditions of significant increase in international competition, efiicient innovations and rapid technological progress.

Some indicators of financial security in Ukraine have to be studied under conditions of deepening of global financial instability, increasing threats to all parts of the financial security of the state. This is important, because the peculiarities of the domestic economic and financial system and modern economic realities (transnationalization deepening, the pace of economic development on a global scale) are changing. In the context of accelerated globalization of the world economy, one of the most important problems in Ukraine is the increase of threats to financial security of the country. Problems in the field do not allow to create conditions for effective growth of the national economy.

\section{LITERATURE REVIEW}

A number of articles and monographs are devoted to issues of financial security and ensuring of its effectiveness on the state level. The role of financial security in economic growth is a scientific problem. Theoretical and practical aspects of financial security and its role in national economies of the countries and under the conditions of and Sayenko (2011), Vashai (2012), Zhalilo (2011), Heyets, Kyzym, Klebanova, and Chernyak (2006), Sukhorukov, and Kharazishvili (2012), Revak (2009). The impact of selected indicators of national economies on the country's financial security was considered by scientists: Samih Antoine Azar (2014), Wenjuan Pan (2014), Vasylieva (2017), Velychko (2014), Lekha S Chakraborty and Darshy Sinha (2018), Manh-Trung Phung, Cheng-Ping Cheng and Chen-Yu Kao (2018).

For example, Christian Weller, Nari Rhee and Carolyn Arcand study financial Security for families and persons in their paper "Financial Security Scorecard: A State-by-State Analysis of Economic Pressures Facing Future Retirees" (2014). They say that in every state, an aging workforce faces an insecure economic future. State policymakers may find the results of the Financial Security Scorecard helpful in identifying the most urgent priorities in addressing the looming financial security challenges of their aging populations. They construct a state aging Financial Security Scorecard that measures performance in three sources of potential economic pressures for future retirees.

Pochenchuk (2014) analyzes financial security of the state. Financial security is conditioned by the ability of public authorities to provide sustain- ability of national financial-economic development and payment and settlement system, observance of basic financial economic parameters of national economics, optimal allocation and rational utilization of budgetary resources, as well as by the ability to make external borrowings optimal for the national economy and effectively utilize them, neutralize the influence of financial crises and deliberate actions of international (states, TNC, interstate formations) and national (clannish-corporate, mafia structures) economic agents on the national economic and socialpolitical system, prevent the outflow of capitals abroad, crimes and administrative delinquencies in the financial area. Thus, the state of national financial security directly depends on governance efficiency.

Siemiątkowski (2017) considers that the development of the global financial market and its consequence (the growth of the global resources of capital) makes economies (especially the developing ones) get threatened with bigger and bigger external financial dangers. Maintaining a specified level of financial security calls for still bigger and bigger efforts on the part of public institutions and commercial entities with respect to managing international transactions. After all, many sources of financial dangers reside in international sphere, or even the global one, and they remain out of full control of the national decision centers. What adds insult to injury is the growth of political risk, which is rising in the recent years. It mainly applies to the relations within the European Union, but it also applies to internal relations. The lack of stability in external and internal relations is an important factor strengthening the process of the interference of the threat to economic security of the state. 
Revak (2017) finds financial security to be the fundamental basis of a cost-effective state, which is responsible for long-term policy of financial stabilization and economic growth. According to experts' forecasts, Ukraine's development over the next decade will be taking place in extremely complex international relations and in conditions of fierce competition in financial markets. The necessity to consolidate economic and financial interests at both macro and micro levels is an indispensable condition for further reforming the financial sector and ensuring balanced development of the national economy as a whole. Bearing this aim in mind, it is necessary to outline key areas for implementing financial policy and identify strategic priorities for strengthening Ukraine's financial security.

Lei Zhang (2014) notes that according to the theory of new economic growth, one of the factors contributing to economic growth is investment. It is important for solving the problems that have arisen in the national economy and they contribute to the continuous development of the economy in terms of transnationalization. The main channels for financing economic development are increasingly attracting public attention.

The fundamentals of the national economy are relatively weak in terms of transnationalization, and domestic sources of finance are increasing, economic development and financial security depend on funding and there is a strong demand for credit. Firstly, financial support is necessary to change the backwardness of agriculture and to improve the rural economy and income of the farmers. The abovementioned measures require large lending. Secondly, the need for financing is vital for the development of small and medium-sized businesses. Thirdly, medium and long-term capital is also needed for strong funding of rural infrastructure and urbanization.

Gabriel Babatunde Iwasokun, Raphael Olufemi Akinyede, and Oniyide Alabi Bello (2018) investigated such an interesting aspect of financial security as financial crime. Scientists confirm that something urgent must be done to restrict the activities of financial criminals. According to this, an investigation into countermeasures against financial crime was conducted. Their research led to the creation of a component matrix that was subjected to orthogonal transformation in order to identify the optimal factorization of variables. The results of the study of Gabriel Babatunde Iwasokun, Raphael Olufemi Akinyede, and Oniyide Alabi Bello (2018) provide a high bonus for control and monitoring, economic and social stability, moral empowerment and partnership, political stability and goodwill as genuine instruments for combating financial crime.

Consequently, most research studies focus on assessing certain aspects of the financial security of national economies. Our research does not only aim at analyzing the current state of financial security indicators of the national economy of Ukraine, but also defines the directions of increasing financial security of Ukraine in the context of transnationalization and national interests on the basis of studying and evaluating the practical bases of this issue.

Aims. The objective of the study is to determine the role of Ukraine's financial security in the context of transnationalization and national interests, based on the study and evaluation of some financial security indicators.

\section{METHODS}

The methodology of the study is based on the early prevention of threats to financial security of Ukraine in the context of transnationalization and national interests, based on both macroeconomic and financial data from the entire financial system. Regression models have been used, because they work dynamically and change only when information changes. Charts can be used by financial analysts to understand the investment attractiveness of the country at the current time with the current level of financial security. Standard models have been designed to predict financial stress and threats to financial security. Financial security models must be built with the support of macroeconomic knowledge, assessment of other risks and expert interpretations, used to get the highest value in the research.

The results are purely statistical, but may be interesting in terms of understanding the patterns and 
trends that affect the financial security of Ukraine in the context of transnationalization and national interests. In order to get an accurate understanding of financial conditions and threats to the financial security of the country, it is important to conduct a study as widely as possible to evaluate the processes occurring in the financial system of the country. This is not only practical, but also reflects how the financial system evolved over time.

\section{RESULTS AND DISCUSSION}

In order to reveal the purpose of the study, the following definition of financial security was used: financial security of the state is a degree of protection of the state's financial interests and main systems, which are financial, monetary, budget, tax, currency, banking, investment, customs, tariff and settlement ones, which are characterized by balance, resistance to internal and external negative influences, capacity of the state to effectively formulate and rationally use financial resources. Let's consider the main financial indicators of Ukraine's financial security. An important quantitative indicator of financial security in Ukraine is the money supply, it connects to all economic relations of the state. The money supply has a sig- nificant effect on almost all indicators of the financial system in Ukraine.

For a more detailed study, a correlation analysis based on statistical data for the period 1990-2017 was conducted to determine the dependence of the money supply on other indicators of the national economy in Ukraine. According to the results of the study, the data obtained are shown in Table 1.

The correlation analysis that has been carried out makes it possible to measure the degree of influence of the factors of the effective indicators on the money supply, to establish a single measure of the tightness of the connection and its role in the overall change of the resultant trait.

The purpose of the correlation analysis is to identify the relationship between different factors. That is, it is determined whether the decrease or increase of one indicator influence on the change of another one. If the dependence is established, then the correlation coefficient is determined. Unlike regression analysis, this is the only indicator that calculates this method of statistical research. The correlation coefficient varies from +1 to -1 . Under a positive correlation, an increase in one indicator contributes to an increase in the other one. Under

Table 1. Influence of separate indicators of the national economy on the money supply of the country

\begin{tabular}{|c|c|c|}
\hline Indicator & Weight & Impact \\
\hline Share of income from which the tax is kept above $10 \%$ & 0.903675 & Direct significant \\
\hline Military expenditures ( $\%$ of central government expenditures) & 0.593770 & Direct moderate \\
\hline Tax on employment and contributions ( $\%$ of income) & 0.526250 & Direct moderate \\
\hline Gross savings (\% of GDP) & -0.058120 & Reverse moderate \\
\hline Multilateral debt (\% of total external debt) & 0.755143 & Direct significant \\
\hline Other taxes (\% of revenue) & -0.504880 & Reverse moderate \\
\hline Export of fuel (\% of exports of goods) & 0.544035 & Direct moderate \\
\hline Formation of fixed capital by the private sector (\% of GDP) & -0.906430 & Reverse significant \\
\hline Domestic credit granted by the financial sector ( $\%$ of GDP) & 0.565165 & Direct moderate \\
\hline Other costs (\% of total costs) & 0.475857 & Direct moderate \\
\hline Total reserves (\% of total external debt) & -0.622490 & Reverse moderate \\
\hline Interest payments on external debt (\% of GNI) & -0.806220 & Reverse significant \\
\hline Direct foreign investment, net inflow (\% of GDP) & -0.448190 & Reverse moderate \\
\hline Exports of information and consulting services (\% of service exports) & 0.123017 & Direct moderate \\
\hline $\begin{array}{l}\text { Interest payments on external debt (\% of exports of goods, services and primary } \\
\text { income) }\end{array}$ & -0.066580 & Reverse moderate \\
\hline Foreign debt rates (\% of GNI) & 0.602822 & Direct moderate \\
\hline Services, value added (\% of GDP) & 0.640900 & Direct moderate \\
\hline Tax revenue, UAH & 0.340332 & Direct moderate \\
\hline Transport services (\% of commercial services imports) & 0.608396 & Direct moderate \\
\hline
\end{tabular}


Source: World Bank database, the Ministry of Finance of Ukraine, the National Bank of Ukraine, authors' calculations.

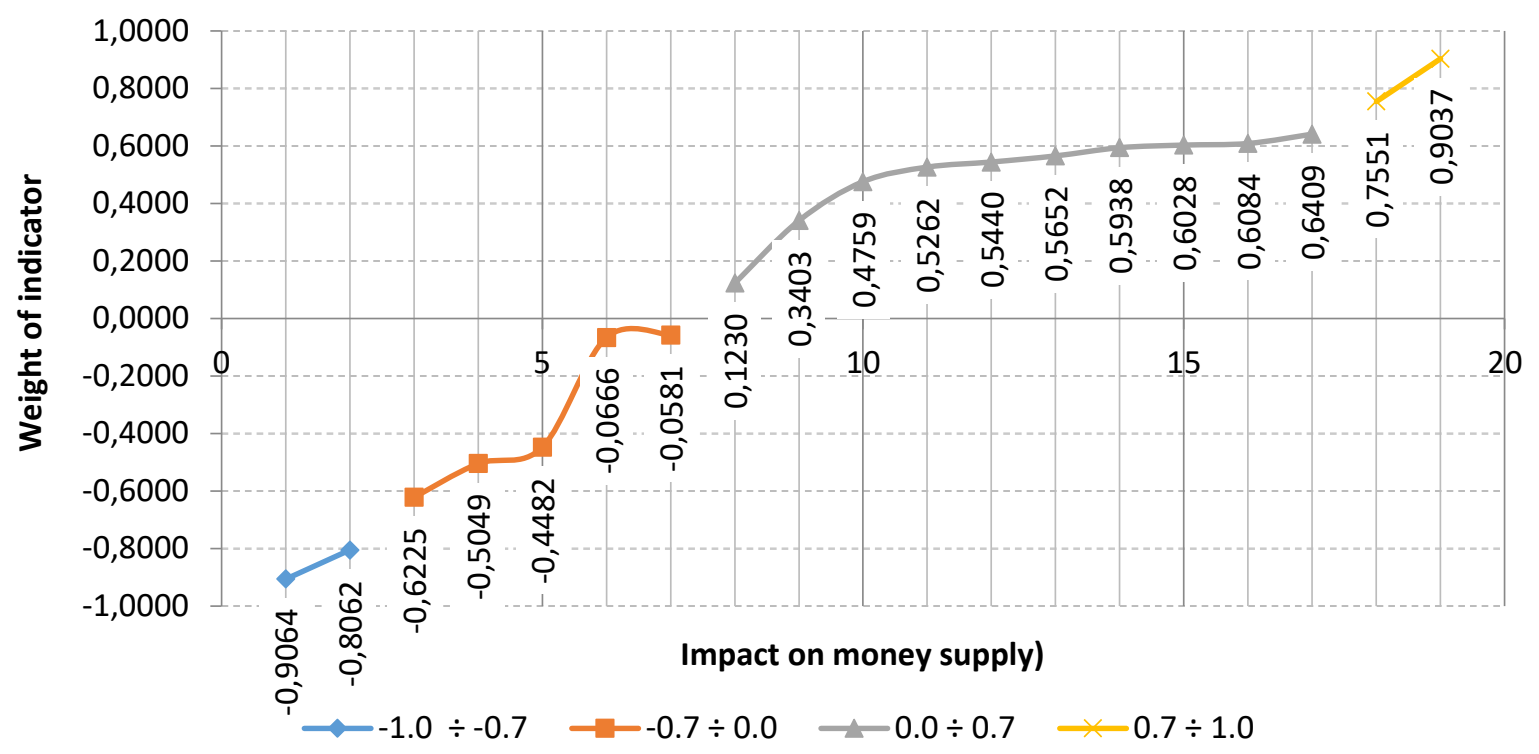

Figure 1. Grouping of the national economy indicators of Ukraine according to the impact on the money supply

a negative correlation, an increase in one indicator causes a decrease in the other one. The more a modulus of the correlation coefficient is, the more visible the change of one indicator reflects the change of another one. When the coefficient is equal to 0 , there is no dependence between them.

Thus, the degree of influence on the money supply, depending on the weight of the indicator, is divided into four groups:

- $-1.0 \div-0.7$ - reverse significant impact;

- $\quad-0.7 \div 0.0$ - reverse moderate impact;

- $0.0 \div 0.7$ - direct moderate impact;

- $0.7 \div 1.0$ - direct significant impact.

The received data are shown in Figure 1.

According to the results of the study, a significant dependence of the money supply on the indicators of the national economy of Ukraine has been found.

Direct significant impact of indicators of the national economy of Ukraine on the money supply is shown in Figure 2.

Analyzing Figure 2, we can conclude that the size of the money supply essentially depends on the indicator "Share of income kept above 10\%" (the correlation coefficient is 0.903675 ); the dependence of the money supply on the indicator "Multilateral debt (\% of total external debt)" is at the level of 0.755143 .

Reverse significant impact of the indicators of the national economy of Ukraine on the money supply is shown in Figure 3. Correlation analysis of the impact of the indicator "Formation of fixed capital, private sector (\% of GDP)" on the money supply shows a significant feedback, correlation coefficient is -0.90643 ; "Influence of the indicator "Interest payable on external debt (\% of GNI)" is the correlation coefficient at the level of -0.80622 .

Considering all mentioned above, in order to increase the level of financial security, it is necessary to develop a set of effective measures aimed at optimizing the financial system indicators in order to increase the level of financial security of the country in the context of national interests.

For a more detailed study, a correlation analysis of some financial security indicators of the country has been conducted: adjusted net national income (annual percentage increase), total government debt (as a percentage of GDP), GINI index (World Bank assessment), inflation, GDP deflator (annual percentage). The presence or absence of a correlation connection is shown in Table 2. 


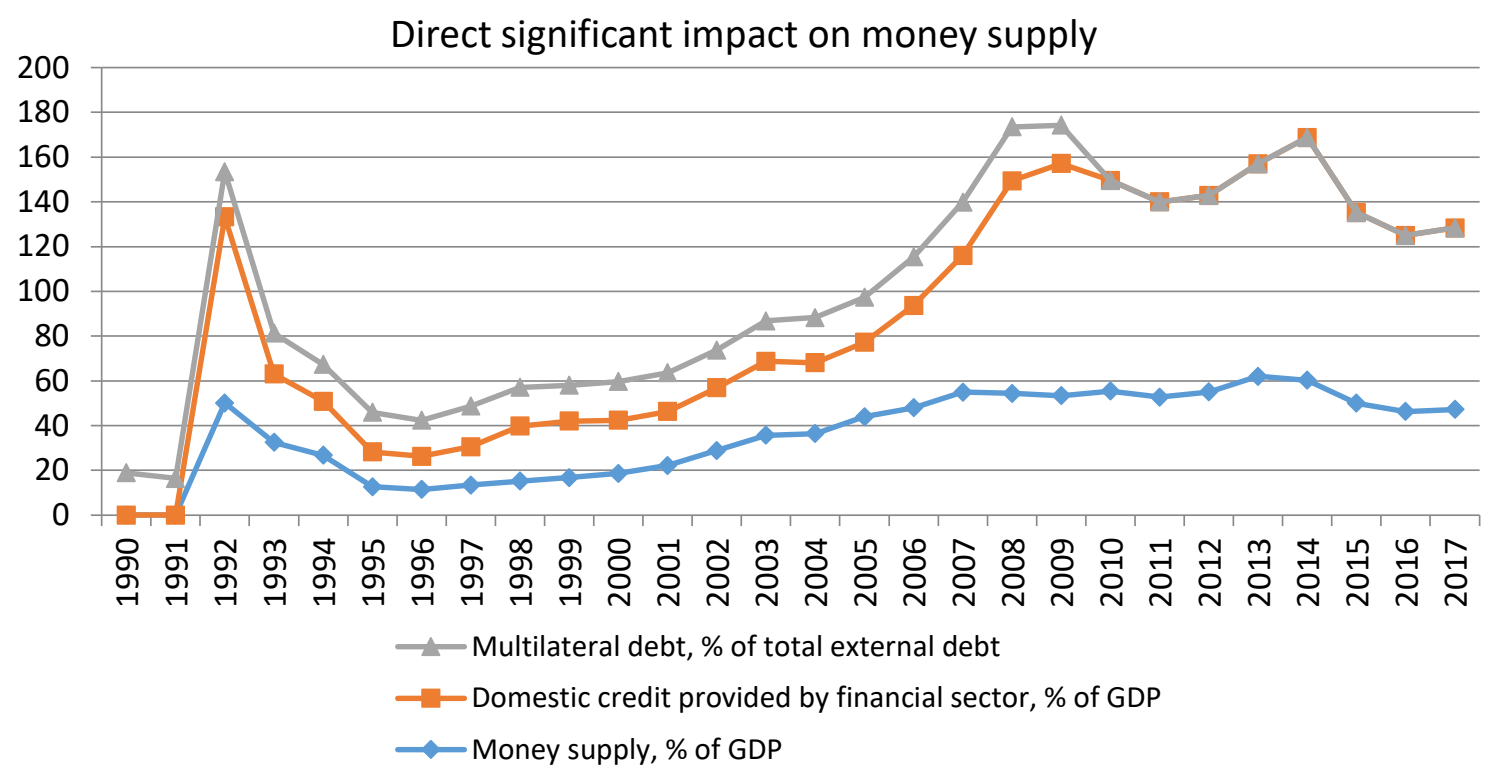

Figure 2. Direct significant impact of indicators of the national economy of Ukraine on the money supply

In the study, after correlation analysis, the adjust- income per capita; interest on new external debt ed net national income, government debt, GINI index (according to the World Bank), inflation were compared with 125 indicators that affect the country's financial security. Correlations showed the following indicators: adjusted net national obligations; the ratio of bank reserves to bank assets; claims to the central government; claims to other sectors of the national economy; preferential debt; debt servicing; internal loan provided by the financial sector; internal loan to the private sec-

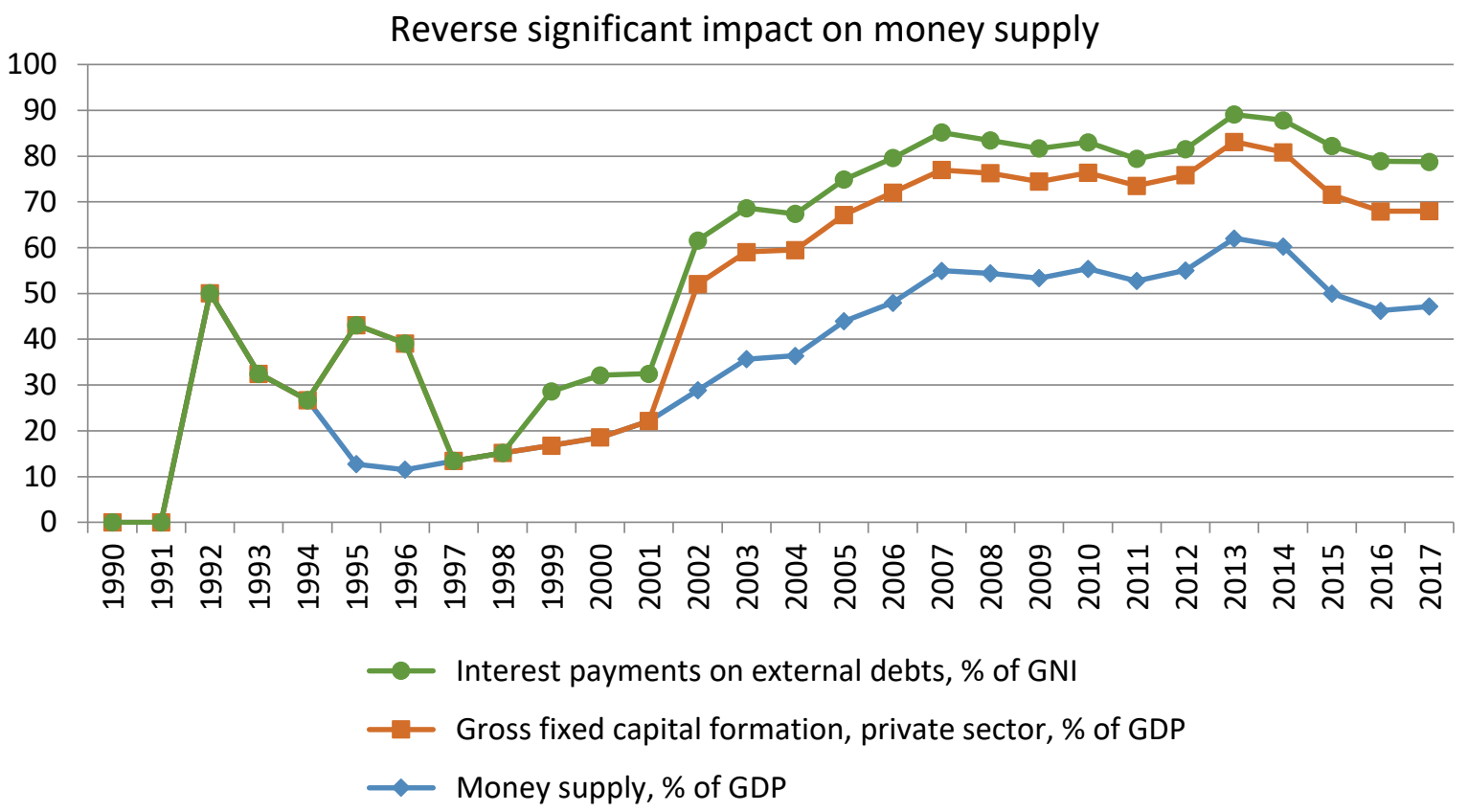

Figure 3. Reverse significant impact of the national economy indicators of Ukraine on the money supply 
Table 2. Correlation coefficients of the impact estimation of the national economy indicators of Ukraine on the adjusted net national income

Source: World Bank database, the Ministry of Finance of Ukraine, the National Bank of Ukraine, authors' calculations.

\begin{tabular}{|c|c|}
\hline Indicator & $\begin{array}{c}\text { Adjusted net national income } \\
\text { (annual \% growth) }\end{array}$ \\
\hline Adjusted net national income per capita (annual \% growth) & 0.992853 \\
\hline Adjusted net national income per capita (annual \% growth) & -0.55043 \\
\hline Public debt, total (\% of GDP) & -0.52686 \\
\hline Domestic loan granted by the financial sector (\% of GDP) & -0.58545 \\
\hline Foreign debt rates $(\%$ of $\mathrm{GNI})$ & -0.51384 \\
\hline Final consumption expenditure, etc. (\% of GDP) & 0.897456 \\
\hline Growth of GDP (annual \%) & 0.892078 \\
\hline GDP per capita (annual \%) & 0.604206 \\
\hline Gross capital formation (\% of GDP) & 0.513843 \\
\hline Gross domestic savings (\% of GDP) & 0.534546 \\
\hline Gross capital formation (\% of GDP) & 0.506344 \\
\hline Gross savings (\% of GDP) & -0.56413 \\
\hline Interest payments on external debt (\% of exported goods, services and primary income) & -0.56084 \\
\hline Interest payments on external debt $(\%$ of GNI) & -0.64402 \\
\hline Acquisition of financial assets (\% of GDP) & -0.63264 \\
\hline Total amount of commitments (\% of GDP) & -0.61919 \\
\hline Total debt service (\% of GNI) & -0.54166 \\
\hline
\end{tabular}

tor; domestic loan to the private sector provided by banks; costs; export of goods and services; external balance of goods and services; external debt rates; end-use costs; direct foreign investment, net inflow; FDI, net outflow; GDP growth; GDP per capita; state budget expenditures on final consumption; GINI index; grants and other income; gross capital formation; gross domestic savings; gross fixed capital formation of the private sector; gross expenses in the country; gross savings; inflation; interest payments on external debt; interest rate on lending; production; military expenditures; multilateral debt; servicing multilateral debt; acquisition of financial assets; obligation; net lending (+) / net borrowing (-); population growth; short-term debt; tax receipts; total debt servicing amount; general reserves; use of IMF loan.

Having selected indicators with the correlation coefficient value more than 0.5 , the following values of the correlation coefficient have been received (Table 2).

According to the results of the calculations presented in Table 2, the most significant impact on the adjusted gross national income is on the indicators: GDP growth (correlation coefficient 0.89 - direct effect); GDP per capita (correlation coefficient 0.89 - direct effect); gross capital formation (correlation coefficient -0.60 - direct effect); acquisition of financial assets (correlation coefficient -0.64 - reverse effect); total liabilities (correlation coefficient -0.63 - reverse effect); total debt servicing amount (correlation coefficient -0.61 - reverse effect).

Table 3 summarizes the coefficients of the correlation of the impact estimation of the national economy indicators of Ukraine on the total amount of public debt.

Table 3. Correlation coefficients of the impact estimation of the national economy indicators of Ukraine on the total amount of the state debt

Source: World Bank database, the Ministry of Finance of Ukraine, the National Bank of Ukraine, authors' calculations.

\begin{tabular}{l|c}
\hline \multicolumn{1}{c}{ Indicators } & $\begin{array}{c}\text { Public debt, total } \\
\text { (\% of GDP) }\end{array}$ \\
\hline $\begin{array}{l}\text { Adjusted net national income (annual } \\
\text { \% growth) }\end{array}$ & -0.55043 \\
\hdashline $\begin{array}{l}\text { Adjusted net national income per } \\
\text { capita (annual \% growth) }\end{array}$ & -0.52891 \\
\hline $\begin{array}{l}\text { The ratio of bank reserves to bank } \\
\text { assets (\%) }\end{array}$ & -0.52352 \\
\hdashline $\begin{array}{l}\text { Claims to the central authority (annual } \\
\text { growth in \% to total money) }\end{array}$ & 0.687364 \\
\hline $\begin{array}{l}\text { Claims to the central government, etc. } \\
\text { (\% of GDP) }\end{array}$ & 0.909421 \\
\hline $\begin{array}{l}\text { Debt service (PPG and IMF only, \% of } \\
\text { exported goods, services and primary } \\
\text { income) }\end{array}$ & 0.607257 \\
\hline
\end{tabular}


Table 3 (cont.). Correlation coefficients of the impact estimation of the national economy indicators of Ukraine on the total amount of the state debt

\begin{tabular}{|c|c|}
\hline Indicators & $\begin{array}{c}\text { Public debt, total } \\
(\% \text { of GDP })\end{array}$ \\
\hline $\begin{array}{l}\text { Domestic loan granted by the financial } \\
\text { sector (\% of GDP) }\end{array}$ & 0.590996 \\
\hline Foreign debt rates ( $\%$ of GNI) & 0.838888 \\
\hline $\begin{array}{l}\text { Final consumption expenditure, etc. }(\% \\
\text { of GDP) }\end{array}$ & 0.61105 \\
\hline Growth of GDP (annual \%) & -0.59962 \\
\hline GDP per capita (annual \%) & -0.56744 \\
\hline Gross capital formation (\% of GDP) & -0.61269 \\
\hline Gross domestic savings (\% of GDP) & -0.61105 \\
\hline Gross capital formation (\% of GDP) & -0.78093 \\
\hline $\begin{array}{l}\text { Gross fixed capital formation, private } \\
\text { sector ( } \% \text { of GDP) }\end{array}$ & -0.77271 \\
\hline Gross savings ( $\%$ of GDP) & -0.61473 \\
\hline $\begin{array}{l}\text { Interest payments on external debt } \\
\text { (\% of exported goods, services and } \\
\text { primary income) }\end{array}$ & 0.808839 \\
\hline $\begin{array}{l}\text { Interest payments on external debt } \% \\
\text { of GNI) }\end{array}$ & 0.861381 \\
\hline Production, value added (\% of GDP) & -0.79679 \\
\hline $\begin{array}{l}\text { Multilateral debt (\% of total external } \\
\text { debt) }\end{array}$ & 0.501082 \\
\hline $\begin{array}{l}\text { Net acquisition of financial assets (\% } \\
\text { of GDP) }\end{array}$ & 0.613227 \\
\hline Net liability, total (\% of GDP) & 0.589494 \\
\hline Population growth (annual \%) & 0.598019 \\
\hline $\begin{array}{l}\text { Short-term debt }(\% \text { of total external } \\
\text { debt) }\end{array}$ & -0.77386 \\
\hline Tax revenues (\% of GDP) & 0.613052 \\
\hline Total debt service (\% of GNI) & 0.771284 \\
\hline Total reserves (\% of total external debt) & -0.69458 \\
\hline Using the IMF loan (US \$) & 0.603805 \\
\hline
\end{tabular}

The correlation coefficients of the impact evaluation of national economy indicators in Ukraine on the GINI index are shown in Table 4.

Table 4. Correlation coefficients of the impact evaluation of the national economy in Ukraine on the GINI index

Source: World Bank database, the Ministry of Finance of Ukraine, the National Bank of Ukraine, authors' calculations

\begin{tabular}{|c|c|}
\hline Indicators & $\begin{array}{l}\text { GINI Index } \\
\text { (World Bank } \\
\text { rating) }\end{array}$ \\
\hline $\begin{array}{l}\text { State budget expenditures on final } \\
\text { consumption (\% of GDP) }\end{array}$ & -0.54475 \\
\hline Lending interest rate $(\%)$ & -0.71749 \\
\hline $\begin{array}{l}\text { Military expenditures (\% of central } \\
\text { government expenditures) }\end{array}$ & -0.66409 \\
\hline $\begin{array}{l}\text { Multilateral debt (\% of total external } \\
\text { debt) }\end{array}$ & -0.64253 \\
\hline Total reserves (\% of total external debt) & 0.514435 \\
\hline
\end{tabular}

Having conducted a correlation analysis of the effect on inflation of 125 indicators, the results showed only a significant impact of the indicator "Maintenance of multilateral debt (\% of state guaranteed debt service)" - the correlation coefficient is -0.55167 .

In the study, we analyze the indicators that can be included in the regression model and those that may be additional to the model for testing and making additional improvements. In each category of risk, there are some indicators that are more important than others. The main innovation is the use of dynamic modeling approach, which is used to optimize financial security and forecast performance with the use of new information.

The model creates a risk warning system for risk prediction based on current national economy indicators in times of uncertainty. When more observations are used, the model improves its predicted performance. Therefore, the problem is to combine all data into a model that can predict whether current financial conditions can lead to a decrease in financial security over a year.

In Table 5, the main indicators that assess the quality of a linear model constructed as a result of regression analysis have been presented.

In the considered example, the value of determination coefficient $R$ is $0.93(>0.5)$, which indicates the existence of a close linear relationship between the amount of public debt and the investigated indicators. The coefficient $R$-square ( $R$-square) in the example considered is 0.928 . This means that the constructed regression model describes $92.8 \%$ of the cases of the indicators influence of the regression model on the size of the public debt. This should be taken into account when applying the results of the analysis in planning the country budget.

$$
\begin{aligned}
& Y=117,99 X 1+119,12 X 2+0,17 X 3+ \\
& +0,27 X 4+0,86 X 5+2,31 X 6+0,11 X 7- \\
& -0,51 X 8-6,01 X 9-126,74 X 10+ \\
& +125,47 X 11+1,18 X 12+6,73 X 13- \\
& -4,28 X 14-2,92 X 15,
\end{aligned}
$$


Table 5. Calculated indicators of state debt regression analysis

Source: World Bank database, the Ministry of Finance of Ukraine, the National Bank of Ukraine, authors' calculations.

Results

\begin{tabular}{l|c}
\hline Regression statistics & \\
\hline Multiple $R$ & 0.939119 \\
\hline$R$-square & 0.928239 \\
\hline Normalized R-square & 0.911818 \\
\hline Standard error & 4.381785 \\
\hline Observations & 17 \\
\hline
\end{tabular}

\begin{tabular}{|c|c|c|c|c|c|c|}
\hline \multicolumn{7}{|c|}{ Dispersion analysis } \\
\hline & $D f$ & $S S$ & MS & $F$ & Significance $\boldsymbol{F}$ & - \\
\hline Regression & 15 & 10881.3 & 725.42 & 37.782 & 0.12706 & - \\
\hline Remnants & 1 & 19.20004 & 19.2004 & - & - & - \\
\hline Total & 16 & 10900.5 & - & - & - & - \\
\hline Variables & Coefficients & Standard error & $T$-statistics & $P$-value & Lower 95\% & Upper 95\% \\
\hline$Y$ & 467.08 & 186.5489 & 2.50383 & 0.2419 & -1903.24 & 2837.41 \\
\hline$x 1$ & 117.99 & 36.06439 & 3.27166 & 0.1888 & -340.251 & 576.232 \\
\hline$x 2$ & -119.12 & 36.05172 & -3.30423 & 0.1870 & -577.204 & 338.957 \\
\hline$x 3$ & 0.1775 & 0.793345 & 0.22380 & 0.8598 & -9.90285 & 10.2579 \\
\hline$x 4$ & 0.2726 & 0.814926 & 0.33453 & 0.7944 & -10.082 & 10.6272 \\
\hline$x 5$ & 0.8635 & 1.212607 & 0.71214 & 0.6060 & -14.5441 & 16.2711 \\
\hline$x 6$ & 2.3173 & 1.064777 & 2.17633 & 0.2742 & -11.212 & 15.8465 \\
\hline$x 7$ & 0.1183 & 0.228567 & 0.51773 & 0.6958 & -2.78588 & 3.02255 \\
\hline$x 8$ & -0.5111 & 0.323414 & -1.58057 & 0.3591 & -4.62054 & 3.59818 \\
\hline$x 9$ & -6.0196 & 2.030238 & -2.96502 & 0.2070 & -31.8163 & 19.7769 \\
\hline$x 10$ & -126.74 & 37.91045 & -3.34323 & 0.1850 & -608.441 & 354.954 \\
\hline$X 11$ & 125.47 & 38.28322 & 3.27753 & 0.1885 & -360.96 & 611.909 \\
\hline$X 12$ & 1.1871 & 1.376133 & 0.86267 & 0.5468 & -16.2983 & 18.6725 \\
\hline$X 13$ & 6.7368 & 3.580243 & 1.88168 & 0.3109 & -38.7544 & 52.2281 \\
\hline$X 14$ & -4.2829 & 1.761422 & -2.43151 & 0.248 & -26.6639 & 18.098 \\
\hline$\times 15$ & -2.92 & 2.059423 & -1.422 & 0.390 & -29.09 & 23.238 \\
\hline
\end{tabular}

where $Y$ is the size of the public debt; $X 1$ - adjusted net national income (annual \% growth); $X 2$ - adjusted net national income per capita (annual\% growth); X3 - ratio of bank reserves to bank ast sets (\%); X4 - claims to the central authority (ant nual growth in $\%$ to the total amount of money); $\mathrm{X} 5$ - claims to the central government, etc. (\% of GDP); X6 - debt service (\% of exported goods, serd vices and primary income); X7 - domestic loan provided by the financial sector (\% of GDP); X8 - rates of external debt (\% of GNI); X9 - final consumption expenditure, etc. (\% of GDP); X10 - GDP growth (annual \%); X11 - GDP per capita (annual $\%$ ); X12 - gross capital formation (\% of GDP); X13 - gross fixed capital formation (\% of GDP); X14 gross fixed capital formation, private sector (\% of GDP); X15 - gross savings (\% of GDP).

Thus, there were proposed the following measures to strengthen the financial security in Ukraine: to increase the stability of the currency, incorporat- ing the tools of the monetary policy in a way to ensure the stability of demand for money, and not to lead to significant higher prices; reducing the level of dollarization of the economy, ensuring the price and exchange rate stability, the development of the dynamics of the nominal exchange rate of the national currency, the use of instruments for hedging currency risks; ensuring the implementation of counteracting shadowing of monetary sphere and criminalization of the cash flow, as shadow economy is one of the factors of the payment crisis, deceleration of the economic growth of national exonomy; provision of control over the maintenance of the proper parameters of the fundamentals of monetary policy for a certain year; - to optimize the structure of national debt in part of between short-term and long-term borrowings; to ensure efficient and effective management of sound (guaranteed) state financial obligations, which provides for the following types of measures: providing a strict control and strict rules 
for giving guaranteed state loans; the implementation of the proper risks distribution between the credit lines; establishing the upper boundary of the state's responsibility in the event of a warranty case; reducing the system of state budget management, reducing the burden on the economy and the budget as a result of the restoration of participants' trust of the domestic and international financial markets to the budget policy and the state loan policy and full compliance with public debt obligations.

Thus, the introduction of a system of measures that covers the main components of the country's financial security will enable Ukraine to increase its financial security provided that these measures are supported at the legislative, executive and state levels. Thus, after analyzing some indicators of Ukraine's financial security over the past few years, we can conclude that there is some improvement in the situation. In the course of the study, a correlation analysis of the country's financial se- curity indexes was made: adjusted net national income, total government debt, GINI index (according to the World Bank), inflation. The presence or absence of a correlation connection was determined. In the study, after conducting a correlation analysis, we compared the adjusted net national income, government debt, GINI index (according to the World Bank), inflation with 125 indicators that affect the country's financial security.

The practical application of indicators to assess the state of financial security of the country is controversial. The calculated procedure of multiple correlation-regression analysis in the article gives an opportunity to evaluate the impact of each of the factors of financial security of the country, and to predict the value of the indicator for the future. The obtained results may be used to develop a methodology for optimal planning of the investigated indicators of financial security in the context of the economic development of the national economy and under the conditions of transnationalization.

\section{CONCLUSION}

In order to make conclusions about the role of financial security in the context of transnationalization and national interests, an assessment of the key components of Ukraine's financial security was conducted in the period 2000-2017.

So, it was concluded that the size of the money supply is significantly dependent on the indicator "Share of revenues, held above 10\%" (the correlation coefficient is 0.903675 ); the dependence of the money supply on the indicator "Multilateral debt (\% of total external debt)" at the level of 0.755143 . The reverse significant impact of the indicators of the national economy of Ukraine on the money supply has also been revealed. Correlation analysis of the impact of the indicator "Formation of fixed capital in the private sector as a percentage of GDP" on the money supply shows a significant feedback, correlation coefficient is -0.90643 ; influence of the indicator "Interest payable on external debt (\% of GNI)" shows the correlation coefficient at the level of -0.80622 .

The results of the calculations show that the adjusted gross national income is most significantly affected by indicators: GDP growth (correlation coefficient 0.89 - direct effect); GDP per capita (correlation coefficient 0.89 - directeffect); gross capital formation (correlation coefficient -0.60 - direct effect); acquisition of financial assets (correlation coefficient -0.64 - reverse effect); total liabilities (correlation coefficient -0.63 - reverse effect); total debt servicing amount (correlation coefficient -0.61 - reverse effect).

Consequently, an important component of the effective functioning of the state is the high level of its financial security in the context of transnationalization and national interests. For an adequate level of financial security, it is necessary to ensure the stability of its components. Thus, in order to ensure budgetary security, it is necessary to legislatively fix and improve budget planning and take measures to reduce budget arrears. Ensuring financial security through regulation of the investment market will enable us to meet the needs of the national economy in the capital, which will further its development. 
Financial security has a significant impact on the process of transnationalization. The impact of financial security on the national economy of the country creates the potential for large, deep and liquid financial markets, which should help to ensure high growth rates of production and employment growth in the country's economy. Such a transformation in the financial and economic landscape poses certain potential risks, but it will provide many opportunities for increasing the efficiency and growth of financial markets and the economy of the country. Ukraine faces new challenges, sometimes rapid and deep economic, social and political transformations, driven by the growth of knowledge and innovation. Ukraine must stimulate its economy, solve new threats and position itself in a competitive world, transformed technologies, global competitiveness and geopolitical changes. In this context, the role of financial security in the context of transnationalization and national interests will be the key to the future of Ukraine.

\section{REFERENCES}

1. Andrianova, S., Demetriades, P., \& Shortland, A. (2012). Government Ownership of Banks, Institutions and Economic Growth. Economica, 79, 449-469. https://doi.org/10.1111/j.14680335.2011.00904.x

2. Baranovsky, O. I. (2004). Фінансова безпека в Украӥні (методологія оцінки та механізми забезпечення) [Finansova bezpeka $v$ Ukraini (metodolohiya otsinky ta mekhanizmy zabezpechennia)] (760 p.). Kyiv: KNTEU.

3. Chen, H.-K., Liao, Y.-C., Lin, C.Y., \& Yen, J.-F. (2018). The Effect of the Political Connections of Government Bank CEOs on Bank Performance During the Financial Crisis. Journal of Financial Stability, 36, 130-143. https://doi. org/10.1016/j.jfs.2018.02.010

4. Chortareas, G. E., Girardone, C., \& Ventouri, A. (2012). Bank Supervison, Regulation and Efficiency: Evidence from European Union. Journal of Financial Stability, 8(4), 292-302. https://doi. org/10.1016/j.jfs.2011.12.001

5. Chakraborty, L. (2016). Fiscal Consolidation, Budget Deficits and Macroeconomic Activity. New Delhi, UK: Sage Publications.

6. Du, Jie (2012). Shandong province small and medium-sized enterprise financing problems and countermeasures research (Master dissertation, Shandong University, 2013). Dissertation Abstracts International, 42, 476.
7. Gabriel Babatunde Iwasokun, Raphael Olufemi Akinyede, \& Oniyide Alabi Bello (2018). Principal Components-based Investigative Study of Counter Measures to Financial Crimes. International Journal of Financial Research, 9(2), 150-164. https://doi.org/10.5430/ ijfr.v9n2p150

8. Heyets, V. M., Kyzym, M. O., Klebanova, T. S., \& Chernyak, O. I. (2006). Моделювання економічної безпеки: держава, регіон, підприємство: монограбія [Modeliuvannia ekonomichnoi bezpeky: derzhava, rehion, pidpryiemstvo: monohrafiia] (240 p.). Kharkiv: KhNEU.

9. Hudym, K. M., Khalatur, S. M. (2016). Systematization and analyse of TNCs' conduct model during coming into the national agrarian markets. Ekonomichnyi chasopys, XXI. Economics and management of national economy, 159(5-6), 34-37. Retrieved from http://soskin.info/userfiles/file/ Economic-Annals-pdf/DOI/eaV159-07.pdf

10. Kharazishvili, Yu. M., Dron, Е. V. (2014). Прогнозування індикаторів, порогових значень та рівня економічної безпеки України в середньостроковій перспективі: аналіт. доп. [Prohnozuvannia indykatoriv, porohovykh znachen ta rivnia ekonomichnoi bezpeky Ukrainy u serednostrokovii perspektyvi: analit. dop.] (117 p.). Kyiv: NISS.

11. Lei Zhang (2014). An Analysis of the Relationship between the Finance and the Economic Growth of Counties in China's Shandong Province. International Journal of Financial Research, 5(2), 29-34. http://dx.doi.org/10.5430/ ijfr.v5n2p29

12. Lekha S Chakraborty, \& Darshy Sinha (2018). Has Fiscal Rules changed the Fiscal Behaviour of Union Government in India? Anatomy of Budgetary Forecast Errors in India. International Journal of Financial Research, 9(3), 75-85. https://doi.org/10.5430/ijfr. v9n3p75

13. Manh-Trung Phung, Cheng-Ping Cheng, \& Chen-Yu Kao (2018). Ownership Structure and Efficiency of Banking Industry in China and Vietnam - A Political View. International Journal of Financial Research, 9(3), 62-74. https://doi. org/10.5430/ijfr.v9n3p61

14. Mishkin, F. S. (2013). The economics of money, banking, and financial markets (10th global ed.). Boston: Pearson.

15. Pochenchuk, G. (2014). Issues of country financial security governance. Forum Scientiae Oeconomia, 2, 27-37.

16. Revak, I. (2017). Стратегічні напрями зміцнення фінансової безпеки України [Stratehichni napriamy zmitsnennia finansovoi bezpeky Ukrainy]. Naukovi zapysky Natsionalnoho universytetu "Ostrozka akademiia". Seriia "Ekonomika": naukovyi zhurnal, 7(35), 72-76.

17. Revak, I. O. (2009). Механізм забезпечення фінансової 
безпеки України: Теоретичний аспект [Mekhanizm zabezpechennia finansovoi bezpeky Ukrainy: Teoretychnyi aspekt]. Naukovyi visnyk Lvivskoho derzhavnoho universytetu vnutrishnikh sprav. Seriia ekonomichna, 2, 1-10.

18. Samih Antoine Azar (2014) Foreign Reserve Accretion and Money Supply Creation: Lebanon's Experience under an Adjustable Peg. International Journal of Financial Research, 5(3), 86-95. http://dx.doi.org/10.5430/ijfr. v5n3p86

19. Siemiątkowski, P. (2017). External financial security of the European Union member states outside the Eurozone. Journal of International Studies, 10(4), 84-95. https://doi. org/10.14254/2071-8330.2017/10 $4 / 6$

20. Sukhorukov, A. I., \& Kharazishvili, Yu. М. (2012). Моделювання та прогнозування соціальноекономічного розвитку регіонів України: монограбія [Modeliuvannia ta prohnozuvannia sotsialno-ekonomichnoho rozvytku rehioniv Ukrainy: monohrafia] (368 p.). Kyiv: NISS.

21. Sukhorukov, A. I., \& Kharazishvili, Yu. М. (2013). Щодо методології комплексного оцінювання економічної безпеки держави [Shchodo metodolohii kompleksnoho otsinyuvannia skladnykiv ekonomichnoi bezpeky derzhavy]. Stratehichni priorytety, 3(28), 5-15.

22. Vlasyuk, O. S. (2008). Теорія $i$ практика економічної безпеки в системі науки про економіку: монограбія [Teoriia i praktyka ekonomichnoi bezpeky v systemi nauky pro ekonomiku: monohrafiia] (48 p.) Kyiv: NIPMB.

23. Varnalii, Z. S., Burkaltseva, D. D., \& Sayenko, O. S. (2011). Економічна безпека України: проблеми та пріоритети зміцнення: монографбія [Еkonomichna bezpeka Ukrainy: problemy ta priorytety zmitsnennia: monohrafia] (299 p.). Kyiv: Znannia Ukrainy.

24. Vasylieva, N. (2017). Economic aspects of food security in Ukrainian meat and milk clusters. Agris On-line Papers in Economics and Informatics, 9(3), 81-92. https:// doi.org/10.7160/aol.2017.090308

25. Vashai, Yu. V. (2012). Шляхи підвищення рівня фінансової безпеки України на сучасному етапі [Shliakhy pidvyshchennia rivnia finansovoi bezpeky Ukrainy na suchasnomu etapi]. Halytskyi ekonomichnyi visnyk, 6(39), 137-144.

26. Velychko, O. (2014). Fundamental basis and connection of modern entrepreneurial logistics and SCM. Review of European Studies, 6(4), 135-146. https://doi.org/10.5539/ res.v6n 4 p 135

27. Weller, Christian, Rhee, Nari, \& Arcand, Carolyn (2014). Financial Security Scorecard: A State-byState Analysis of Economic Pressures Facing Future Retirees (Public Policy and Public Affairs Faculty Publication Series. Paper 49). Retrieved from http://scholarworks. umb.edu/pppa_faculty_pubs/49

28. Wenjuan Pan (2014). On Risk Comprehensive Evaluation of Carbon Finance in Commercial Banks under Low-Carbon Economy in China. International Journal of Financial Research, 5(4), 139-143.

29. Zhalilo, Ya. A. (2001). Cmpameziя національної безпеки України в контексті досвіду світової спільноти: монограбія [Stratehiia natsionalnoi bezpeky Ukrainy $v$ konteksti dosvidu svitovoi spilnoty: monohrafiia] (224 p.). Kyiv: Satsang. 